\title{
Post-natal "mesenchymal" stem cells: the assayable skeletal potency
}

\author{
Sacchetti $\mathrm{B}^{1}$
}

Key Words: Skeletal progenitors; Mesenchymal stem cells; In vitro assays; In vivo assays; Transplantation; Differentiation

Post-natal "Mesenchymal" Stem Cells (MSCs) are fibroblastoid multipotent cells with a high capacity for self-renewal. Skeletal Stem Cells (SSCs), also known as Bone Marrow Stromal Cells (BMSCs) or MSCs from Bone Marrow (BM-MSCs), are the best known post-natal mesenchymal progenitors of mesodermic tissues in humans. Skeletal MSCs are perivascular cells in bone marrow, and progenitors of all tissues that together comprise the bone-bone marrow organ (bone, cartilage, fat and perivascular stromal cells; the latter coincide with the skeletal/mesenchymal stem cell and the cell type that provides a niche for hematopoietic stem cells) ${ }^{[1-}$ 4]. They can be prospectively isolated based on phenotype, generate clonal progenies in vitro, and replicate the development of bone/marrow organ (also defined ossicle, including bone and bone marrow) in defined experimental transplantation systems ${ }^{[4,5]}$.

To date, MSCs have been isolated from several human post-natal tissues, e.g., bone marrow, adipose tissue, umbilical cord matrix, tendon, lung, periosteum, dental pulp, synovium and many more $^{[6]}$. Regardless of source, these cells display markers such as CD29, CD44, CD70, CD73, CD90, CD105, and Stro-1, lacking markers for early hematopoietic lineages (CD34, CD45 and others $)^{[7,8]}$. Albeit, the markers for identification of a "true" MSC remain somewhat controversial. However, the biological skeletal properties of MSCs are essentially based on canonical in vitro assays ${ }^{[9]}$ using cultures that are chemically directed towards osteo, adipo- and chondrogenic differentiation (Figure 1A) employing respectively osteogenic, adipogenic and chondrogenic inducers ${ }^{[10]}$. These in vitro assays are not stringent and specific, and often fail to predict in vivo differentiation potential and behavior of a given MSC strain upon in vivo transplantation. In vivo skeletogenic potential of MSCs for osteo-tissue regeneration is not predicted by in vitro detection of tissue-specific phenotypic markers (e.g. mRNA or protein) or by the observation of in vitro surrogates of in vivo differentiated features, such as deposition of alcianophilic matrix (cartilage), mineralization nodules (bone), or intracellular lipid accumulation [(adipocytes); Figure 1A, a-c]. In fact, the expression of osteoblastic markers can be induced in culture, in a variety of manners and in a variety of cells ${ }^{[10]}$ that remain unable to make bone in vivo. The multipotency of MSCs derived from multiple human adult tissue sources is commonly but wrongly believed to be assayable by in vitro differentiation assays. It is generally assumed that MSCs, non-hematopoietic cells, isolated from multiple human adult tissues and expressing minimal criteria for defining human multipotent mesenchymal stromal cells ${ }^{[9]}$, might be induced to proliferate extensively and forwarded to differentiate to osteoblasts, adipocytes and chondroblasts in vitro when appropriately stimulated ${ }^{[10-14]}$. However, there are many methods to induce an osteogenic phenotype in vitro ${ }^{[10]}$. These methods result in the generation of a tissue that does not have the structural organization of bone that is formed in vivo; in many cases, mineralization is due to dystrophic calcification in contrast with the true bone formation. Adipogenesis can also be induced in vitro in different culture conditions ${ }^{[10]}$, but the adipocytes that are formed tend to be multivacuolar (immature), whereas mature adipocytes in marrow are univacuolar (mature) $)^{[15]}$. MSCs generate mature tissue in vivo, not in plastic. Therefore, many "mesenchymal" cell strains are able to "differentiation" as artificially assessed in vitro, however, remain unable to generate bone, cartilage or fat when implanted in conventional in vivo differentiation assays, resulting in the formation of fibrous tissue. Indeed, the skeletogenic capacity of a given cell strain is only proven by in vivo transplantation. The orthotopic bone formation assay (Figure 1B, a) is commonly used to study osteogenesis in vivo. For evaluation of in vivo osteogenic functionality of MSCs, cell-scaffold constructs are transplanted in femoral bone defects in immunodeficient mice (or rabbit) ${ }^{[16,17]}$. When cell-scaffold constructs are implanted in femoral critical size defect, we observe several weeks after transplantation, bone formation in place of fibrous tissue ${ }^{[18]}$. Compared to orthotopic assay, the ectopic bone forming assay (Figure 1B, b-c) has unique advantage since there is no requirement for bone cytokine stimulation and cell-to-cell interaction with endogenous boneforming cells. Heterotopic subcutaneous implantation is the simplest experimental model of ectopic bone formation. However, a variety of ectopic locations can be used for cell implantation, including subcutaneous ${ }^{[19-21]}$, intramuscular ${ }^{[22]}$ sites and the kidney capsule ${ }^{[23-26]}$. Transplantation under the kidney capsule allows implanted MSCs to interact with a recipient environment that provides a rich vascular supply. Issues associated with skeletogenic potential of MSCs in kidney capsule transplants are that in addition to being a technically difficult surgical procedure, only small samples can be transplanted and studied, and the number of samples analyzed per recipient animal is limited. To overcome these limitations, more recent studies have utilized the ability of immunocompromised mice to accept cell transplants in a variety of anatomical sites that allow multiple transplantations ${ }^{[27]}$. The principal aim of these assays is to evaluate in vivo skeletogenic formation capacity of MSCs and follow the fate of implantation together with ceramic scaffold constructs [e.g., using hydroxyapatite/tricalcium phosphate $(\mathrm{HA} / \mathrm{TCP})]$ or as a cell pellet without a vehicle [e.g., growing cells as unmineralized pellets in chondrogenic differentiation medium] in immunocompromised host ${ }^{[5,27,28]}$. Indeed, for transplants, the use and nature of 
A in vitro

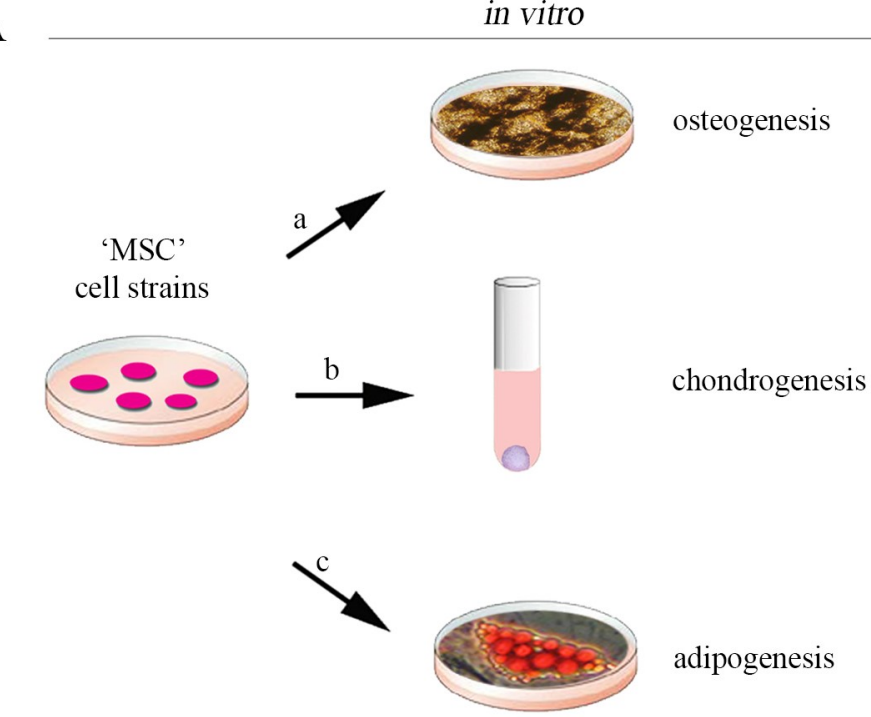

B in vivo
'MSC'
cell strains
attachment
to scaffold

orthotopic transplantation into segmental defect

$\mathrm{a}$

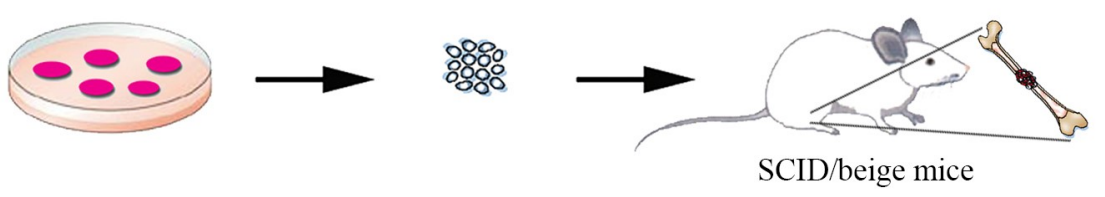

'MSC'

in vitro maturation

heterotopic subcutaneous cell strains

b
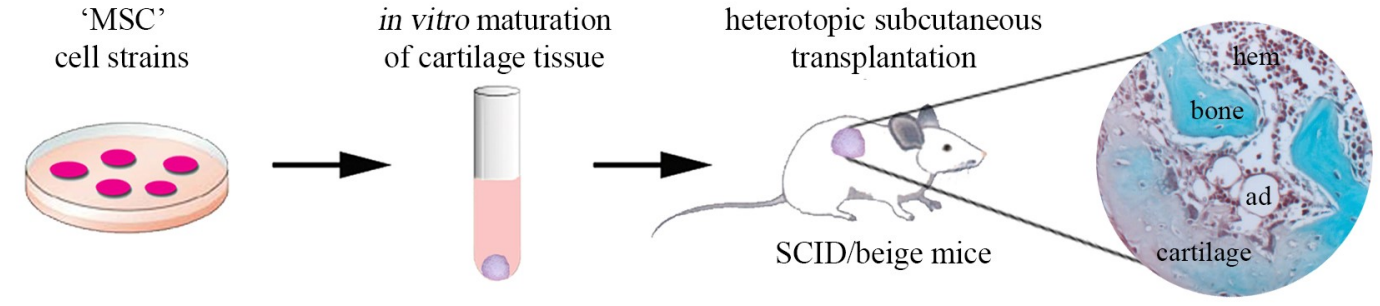

'MSC'

cell strains

attachment

to scaffold

c
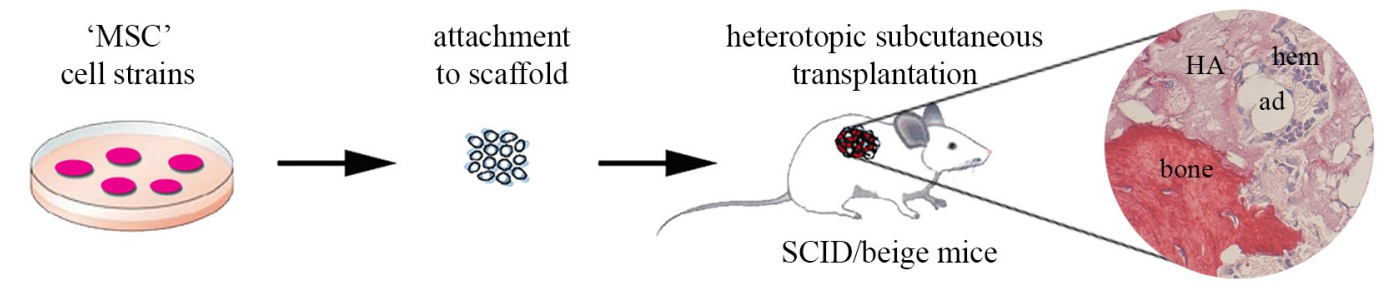

Figure 1. Skeletogenic potential of "mesenchymal"stem cells derived from different adult human tissues: diagram of in vitro assays and in vivo transplantation assay systems. A) Conventional in vitro skeletogenic differentiation assays are conducted using multiclonal MSC strains, derived from different tissues, which are first expanded on plastic, and then cultured/induced under osteogenic (a), chondrogenic (b) and adipogenic (c) conditions. B) Scheme of in vivo skeletogenic transplantation protocol. a) Orthotopic osteogenesis assay, in vivo, with scaffold. In this model, for investigating osteogenic differentiation in vivo at orthotopic sites, cells are loaded onto osteoconductive carriers and then cell/ceramic constructs are transplanted into bone defects mice with injured. b) Heterotopic subcutaneous osteogenesis assay, in vivo, without scaffold. In this model, for investigating osteogenic differentiation at heterotopic sites, cells are grown as unmineralized pellets in chondrogenic differentiation medium and then transplanted into the subcutaneous tissue of immunocompromised (SCID/beige) mice to generate heterotopic skeletal tissues; c) In an heterotopic subcutaneous osteogenesis transplantation assay, cell strains are grown in culture, loaded onto osteoconductive carriers [e.g. using hydroxyapatite/tricalcium phosphate (HA/TCP)] and then transplanted subcutaneously in the back of the immunocompromised SCID/beige mice. Sirius red stains bone intensely due its high collagen content (c). Safranin O stains (orange-violet) chondrocytes and cartilage due to their proteoglycan content and Fast green stains (green-blue) bone matrix (b). HA, hydroxyapatite; ad, adipocyte; hem, hematopoiesis. 
transplantation substrate/vehicle are essential components for successful osteogenesis. Osteogenesis does not proceed when MSC suspensions are injected subcutaneously or intramuscularly, or when MSCs are implanted into rapidly resorbed vehicles ${ }^{[27]}$. Thus, in order to form bone, transplanted MSCs require the presence of an organized carrier in which they can adhere and proliferate for periods long enough to ensure differentiation and osteogenesis. Protocols for the isolation and culture of osteogenic progenitor cells, and the choice and design of osteoconductive carrier, represent the most important open questions in bone tissue engineering and preclinical studies. Of the mineralized vehicles used for MSC transplantation to date, hydroxyapatite-based constructs have been the most successful ${ }^{[27]}$.

\section{Conclusions}

The basis for osteogenic properties of MSC population cannot be validated on the ability to develop biochemical or morphological markers of an osteoblast in vitro. Thus, the finding of alkaline phosphatase positive cells or even a mineralized matrix, particularly when culture cells are treated with potent inducer such as bone morphogenetic proteins (BMPs) or further cultured in osteoinductive medium supplemented with beta-glycerophosphate, dexamethasone and ascorbic acid ${ }^{[10]}$, may not predict how MSCs will behave upon transplantation. While, in vitro assays have empirical but limited value, in vivo assays represent the gold standard toward definition of putative skeletal "mesenchymal" cells for showing true osteogenic potency of any tested cell population. Indeed, no identical post-natal MSCs-committed progenitors are incorporated in human connective tissues $^{[28]}$; native skeletogenic potential is inherent to the system of progenitor/stem cells found in the skeleton. MSCs from BM are able to generate skeletal tissues, in vivo and spontaneously ${ }^{[4,5,28]}$, with no pre-osteogenic induction in culture. Other MSCs derived from different tissues require reprogramming signals in order to acquire skeletogenic capacity ${ }^{[29]}$. MSCs from different post-natal tissues express the same cell surface markers ${ }^{[7,8]}$, similar osteogenic differentiation properties in vitro ${ }^{[10]}$ but different skeletogenic potential in vivo, as indicated using orthotopic and heterotopic in vivo transplantation assay systems ${ }^{[4,16-28]}$, and this can be the reason for their different behavior in clinical applications. Therefore, in vitro studies of MSC osteogenic differentiation show several limitations. In vitro results need to be compared with in vivo pre-clinical studies in order to suggest the best MSC type for clinical skeletal regenerative therapies.

\section{References}

1. Friedenstein AJ. Osteogenic stem cells in bone marrow. In Bone and Mineral Research. Editor(s): Johan N.M. Heersche, John A. Kanis. Elsevier; 1990;243-72.

2. Mendez-Ferrer S, Michurina TV, Ferraro F, Mazloom AR, Macarthur BD, Lira SA, Scadden DT, Ma'ayan A, Enikolopov GN, and Frenette PS. Mesenchymal and haematopoietic stem cells form a unique bone marrow niche. Nature. 2010;466 (7308),829-834.

3. Owen M. Marrow stromal stem cells. J Cell Sci Suppl. 1988;10,63 76.

4. Sacchetti B, Funari A, Michienzi S, Di Cesare S, Piersanti S, Saggio I, Tagliafico E, Ferrari S, Robey PG, Riminucci M, Bianco $\mathrm{P}$. Self-renewing osteoprogenitors in bone marrow sinusoids can organize a hematopoietic microenvironment. Cell. 2007;131 (2),324-36.

5. Serafini M, Sacchetti B, Pievani A, Redaelli D, Remoli C, Biondi A, Riminucci M, and Bianco P. Establishment of bone marrow and hematopoietic niches in vivo by reversion of chondrocyte differentiation of human bone marrow stromal cells. Stem cell research. 2014;12(3),659-72.
6. da Silva Meirelles L, Caplan AI, Nardi NB. In search of the in vivo identity of mesenchymal stem cells. Stem Cells. 2008;26(9):2287-99.

7. Bianco P, Robey PG, Simmons PJ. Mesenchymal stem cells: Revisiting history, concepts, and assays. Cell Stem Cell 2008;2(4):313-19.

8. Chamberlain G., Fox J, Ashton B, Middleton J. Concise review: mesenchymal stem cells: their phenotype, differentiation capacity, immunological features, and potential for homing. Stem Cells. 2007;25 (11):2739-49.

9. Dominici M, Le Blanc K, Mueller I, Slaper-Cortenbach I, Marini F, Krause D, Deans R, Keating A, Prockop D, and Horwitz E. Minimal criteria for defining multipotent mesenchymal stroma cells. The International Society for Cellular Therapy position statement. Cytotherapy. 2006;8(4):315-17.

10. Gimble JM, Guilak F, Nuttall ME, Sathishkumar S, Vidal M, Bunnell BA. In vitro Differentiation Potential of Mesenchymal Stem Cells. Transfus Med Hemother. 2008;35(3):228-38.

11. Bianco P, Cancedda FD, Riminucci M, and Cancedda, R. Bone formation via cartilage models: the "borderline" chondrocyte. Matrix Biol. 1998;17(3):185-92.

12. Johnstone B, Hering TM, Caplan AI, Goldberg VM, and Yoo JU In vitro chondrogenesis of bone marrow-derived mesenchymal progenitor cells. Exp Cell Res. 1998;238(1):265-272.

13. Muraglia A, Corsi A, Riminucci M, Mastrogiacomo M, Cancedda $\mathrm{R}$, Bianco P, and Quarto, R. Formation of a chondro-osseous rudiment in micromass cultures of human bone-marrow stromal cells. J Cell Sci. 2003;116 (Pt 14):2949-55

14. Sekiya I, Vuoristo JT, Larson BL, and Prockop DJ. In vitro cartilage formation by human adult stem cells from bone marrow stroma defines the sequence of cellular and molecular events during chondrogenesis. Proc Natl Acad Sci USA. 2002;99 (7):4397-4402.

15. Kuznetsov SA, Riminucci M, Ziran N, Tsutsui TW, Corsi A, Calvi L, Kronenberg HM, Schipani E, Robey PG, Bianco P. The interplay of osteogenesis and hematopoiesis: expression of a constitutively active PTH/PTHrP receptor in osteogenic cells perturbs the establishment of hematopoiesis in bone and of skeletal stem cells in the bone marrow. J Cell Biol. 2004;20;167(6):111322.

16. Adachi N, Ochi M, Deie M, Ito Y. Transplant of mesenchymal stem cells and hydroxyapatite ceramics to treat severe osteochondral damage after septic arthritis of the knee. J Rheumatol. 2005;32 (8): 1615-1618.

17. Quarto R, Mastrogiacomo M, Cancedda R, Kutepov SM Mukhachev V, Lavroukov A, Kon E, and Marcacci M. Repair of large bone defects with the use of autologous bone marrow stromal cells. N Engl J Med. 2001;344 (5):385-86.

18. Srouji S, Ben-David D, Kohler T, Müller R, Zussman E, Livre E. A model for tissue engineering applications: femoral critical size defect in immunodeficient mice. Tissue Eng Part C Methods. 2011;17(5):597-606.

19. Kuznetsov SA, Krebsbach PH, Satomura K, Kerr J, Riminucci M, Benayahu D, Robey PG. Single-colony derived strains of human marrow stromal fibroblasts form bone after transplantation in vivo. J Bone Miner Res. 1997;12(9):1335-47.

20. Mankani MH, Kuznetsov SA, Fowler B, Kingman A, Robey PG In vivo bone formation by human bone marrow stromal cells: effect of carrier particle size and shape. Biotechnol Bioeng. 2001;72 (1):96-107.

21. Mankani MH, Kuznetsov SA, Marshall GW, Robey PG. Creation of new bone by the percutaneous injection of human bone marrow stromal cell and HA/TCP suspensions. Tissue Eng Part A 2008;14(12): 1949-58.

22. Crisan M, Yap S, Casteilla L, Chen CW, Corselli M, Park TS, Andriolo G, Sun B, Zheng B, Zhang L, Norotte C, Teng PN, Traas J, Schugar R, Deasy BM, Badylak S, Buhring HJ, Giacobino JP, Lazzari L, Huard J, Peault B. A perivascular origin for mesenchymal stem cells in multiple human organs. Cell Stem Cell. 2008;3(3): 301-13.

23. Chan CK, Chen CC, Luppen CA, Kim JB, DeBoer AT, Wei K, Helms JA, Kuo CJ, Kraft DL, Weissman IL. Endochondral ossification is required for haematopoietic stem-cell niche formation. Nature. 2009;22;457(7228):490-4 
24. Friedenstein AJ, Shapiro-Piatetzky II, Petrakova KV. Osteogenesis in transplants of bone marrow cells. J Embryol Exp Morph. 1966;16(3):381-90.

25. Friedenstein AJ, Petrakova KV, Kurolesova AI, Frolova GP. Heterotopic transplants of bone marrow: Analysis of precursor cells for osteogenic and hematopoietic tissues. Transplantation. 1968;6(2):230-47.

26. Reinisch A, Etchart N, Thomas D, Hofmann NA, Fruehwirth M, Sinha S, Chan CK, Senarath-Yapa K, Seo EY, Wearda T, Hartwig UF, Beham-Schmid C, Trajanoski S, Lin Q, Wagner W, Dullin C, Alves F, Andreeff M, Weissman IL, Longaker MT, Schallmoser K, Majeti R, Strunk D. Epigenetic and in vivo comparison of diverse MSC sources reveals an endochondral signature for human hematopoietic niche formation. Blood. 2015;8;125(2):24960 .

\section{Abbreviations}

$\begin{array}{ll}\text { MSCs } & : \text { Mesenchymal Stem Cells } \\ \text { SSCs } & \text { : Skeletal Stem Cells } \\ \text { BMSCs } & \text { : Bone Marrow Stromal Cells } \\ \text { BM-MSCs } & : \text { MSCs from Bone Marrow } \\ \text { HA/TCP } & \text { : Hydroxyapatite/tricalcium phosphate } \\ \text { BMPs } & \text { : Bone morphogenetic proteins } \\ \text { ad } & \text { : Adipocyte } \\ \text { hem } & : \text { Hematopoiesis }\end{array}$

\section{Potential Conflicts of Interests}

None

\section{Corresponding Author}

Sacchetti Benedetto, Department of Science, University ROMA TRE, Viale Marconi, 446 - 00146 Rome, Italy; benedetto.sacchetti@uniroma3.it time. Cell. 2015;160(1-2):17-9.
27. Krebsbach PH, Kuznetsov SA, Bianco P, Robey PG. Bone marrow stromal cells: characterization and clinical application. Crit Rev Oral Biol Med. 1999;10(2):165-81. Review

28. Sacchetti B, Funari A, Remoli C, Giannicola G, Kogler G, Liedtke S, Cossu G, Serafini M, Sampaolesi M, Tagliafico E, Tenedini E, Saggio I, Robey PG, Riminucci M, Bianco P. No identical "mesenchymal stem cells" at different times and sites: Committed progenitors of distinct origin and differentiation potential are incorporated as adventitial cells in microvessels. Stem Cell Reports. 2016;14;6(6):897-913.

29. Kassem M, Bianco P. Skeletal stem cells in space and 